\title{
Influenza-related deaths - available methods for estimating numbers and detecting patterns for seasonal and pandemic influenza in Europe
}

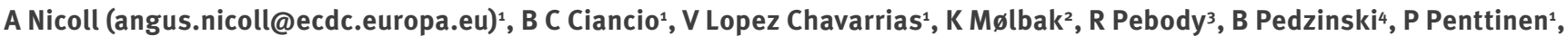

$M$ van der Sande ${ }^{5,6}, R_{\text {Snacken }}^{1}, M^{D}$ D Van Kerkhove ${ }^{7}$

1. European Centre for Disease Prevention and Control, Stockholm, Sweden

2. Statens Serum Institut, Copenhagen, Denmark

3. Health Protection Agency, Colindale, United Kingdom

4. Medical University of Biatystok, Department of Public Health, Białystok, Poland

5. National Institute for Public Health and the Environment (RIVM), Centre for Infectious Disease Control Netherlands, Bilthoven, the Netherlands

6. Julius Centre for Health Sciences and Primary Care, Utrecht University, Utrecht, the Netherlands

7. Medical Research Council Centre for Outbreak Analysis and Modelling, Imperial College London, London, United Kingdom

Citation style for this article:

Nicoll A, Ciancio BC, Lopez Chavarrias V, Mølbak K, Pebody R, Pedzinski B, Penttinen P, van der Sande M, Snacken R, Van Kerkhove MD. Influenza-related deaths available methods for estimating numbers and detecting patterns for seasonal and pandemic influenza in Europe . Euro Surveill. 2012;17(18):pii=20162. Available online: http://www.eurosurveillance.org/ViewArticle.aspx?Articleld=20162

Article submitted on 26 July 2011/ published on 3 May 2012

Two methodologies are used for describing and estimating influenza-related mortality: Individual-based methods, which use death certification and laboratory diagnosis and predominately determine patterns and risk factors for mortality, and population-based methods, which use statistical and modelling techniques to estimate numbers of premature deaths. The total numbers of deaths generated from the two methods cannot be compared. The former are prone to underestimation, especially when identifying influenza-related deaths in older people. The latter are cruder and have to allow for confounding factors, notably other seasonal infections and climate effects. There is no routine system estimating overall European influenza-related premature mortality, apart from a pilot system EuroMOMO. It is not possible at present to estimate the overall influenza mortality due to the 2009 influenza pandemic in Europe, and the totals based on individual deaths are a minimum estimate. However, the pattern of mortality differed considerably between the 2009 pandemic in Europe and the interpandemic period 1970 to 2008 , with pandemic deaths in 2009 occurring in younger and healthier persons. Common methods should be agreed to estimate influenza-related mortality at national level in Europe, and individual surveillance should be instituted for influenza-related deaths in key groups such as pregnant women and children.

\section{Introduction}

The three influenza pandemics of the 2oth century all resulted in substantial premature mortality (referred to as mortality in this review) which has been estimated by various parameters (Table 1$)[1,2]$.

Mortality rates during past pandemics have differed considerably both between pandemics and within the same pandemic $[1,3,4]$. For example, estimates for the United States (US) varied from 30.5 premature deaths per $10^{5}$ population (1968 pandemic) through $53.4 / 10^{5}$ (1957 pandemic) to $450.9 / 10^{5}$ (1918 pandemic) compared with an average of $16.9 / 10^{5}$ for influenza $A\left(\mathrm{H}_{3} \mathrm{~N}_{2}\right)$ dominated seasons from 1979 to 2001 [4]. The pattern of deaths (i.e. mortality rates by age, risk groups, pathogenesis and disease presentation) probably also differed between pandemics and seasonal epidemics, but this is less well documented [5-8]. Viboud et al's analysis in 2010 estimated the mean ages of premature deaths during the 1918, 1957 and 1968 pandemics as 27, 65 and, 62 years, respectively, and as 76 years for seasonal influenza $A\left(\mathrm{H}_{3} \mathrm{~N}_{2}\right)$ from 1979 to 2001 [4]. Finally the annual mortality has differed between seasonal epidemics [9-13]. All this variation is due to a complex mix of factors of which some are real effects on mortality, while others are related to the methodologies used to estimate mortality (Box 1). For example, substantial variations in the estimates of influenzarelated premature mortality have been observed within the same epidemic or pandemic depending on the data sources, the analytic approach, and the geographical setting [14-21]. For these reasons, estimating the extent of influenza-related mortality is complex.

The published rates of deaths for the 2009 pandemic have varied nearly 70 -fold from 0.02 to 1.46 per $10^{5}$ population with a tendency to decline with the time passed between the start of the pandemic and the estimate, with more data being acquired and further analyses undertaken $[4,13,14,22-26]$. There is no evidence of changes in the virus that could be responsible for this decline in the estimates [27]. 
For policy formulation, simply counting numbers of deaths attributable to influenza would be undesirable, even if it were possible. Robust comparable mortality analyses for seasonal and pandemic influenza are needed to determine risk groups, to guide and evaluate distribution of resources, to communicate and prepare the public and policy makers. These analyses have to accommodate some of the complexities mentioned above. The objectives of this review are to summarise the methods for estimating seasonal and pandemic influenza-related mortality, particularly describing the systems in place in Europe, to document and interpret the initial European mortality data for the 2009 pandemic, and to suggest how to develop better approaches to influenza mortality surveillance and estimates for Europe.

\section{Methods for measuring influenza- associated mortality}

The history of estimating influenza-associated mortality is as old as formal death monitoring. William Farr measured the impact of influenza in London in 1847 by subtracting the number of deaths recorded in a relatively influenza-free winter from the number recorded during an epidemic season [28]. In the 2oth and 21st centuries, more sophisticated approaches to estimate mortality were developed and applied, including monitoring cause-specific mortality, statistical and modelling approaches and incorporating virological information into routine systems and special studies $[21,29,30]$ (Table 2).

In the United States (US) it is customary to monitor and model trends in cause-coded death notifications due to pneumonia and influenza or all respiratory, cardiovascular and cerebrovascular conditions, while monitoring all-cause mortality is generally the approach in Europe. Since the 1957 pandemic, the US has had a specific system in place using pneumonia and influenza (P\&I) death data from 122 US cities for estimating influenza mortality $[21,37,38]$. Simpler approaches to measure excess all-cause mortality have been applied in at least eight European countries (Table 3 ) and elsewhere $[15,35,39-47]$. In the following section we critically describe these various methods.

\section{Methods based on individual death certification or laboratory-confirmed cases} Using vital registration data and counting the number of individuals who died with an influenza diagnosis mentioned on their death certificate is straightforward but it is also a method highly liable to result in underdetection, especially for seasonal influenza and in older people $[50,51]$. For example in England and Wales, only 131 deaths were coded with an underlying cause of influenza between 2005 and 2008 when statistical techniques estimated there were over 12,700 premature influenza deaths $[13,46,52]$. In contrast, during

TABLE 1

Definitions relating to influenza mortality

\begin{tabular}{|c|c|c|}
\hline Parameter & Definition & Notes \\
\hline Mortality impact & $\begin{array}{l}\text { Absolute numbers of deaths due to influenza } \\
\text { (seasonal or pandemic) }\end{array}$ & $\begin{array}{l}\text { Needs to be converted to rates according to the population and } \\
\text { period of time. }\end{array}$ \\
\hline Case fatality rate (CFR) & Risk of death among those with clinical disease & Often expressed as a percentage. \\
\hline Infection fatality rate (IFR) & Risk of death among those infected & A measure using serology to estimate the number of infections. \\
\hline $\begin{array}{l}\text { Population fatality rate } \\
\text { (PFR) }\end{array}$ & $\begin{array}{l}\text { Numbers of deaths due to influenza per unit } \\
\text { population }\end{array}$ & Often expressed as per 100,000 resident population. \\
\hline Premature mortality & $\begin{array}{l}\text { A death occurring earlier than it would have } \\
\text { done without the intervention of influenza }\end{array}$ & $\begin{array}{l}\text { Almost all influenza-related deaths are premature. However it } \\
\text { is important to emphasise this point with seasonal influenza } \\
\text { when many of the deaths are focused in older people and so } \\
\text { are less premature than they would be in younger people. }\end{array}$ \\
\hline $\begin{array}{l}\text { Influenza infection and } \\
\text { disease }\end{array}$ & $\begin{array}{l}\text { Influenza is here defined as a laboratory- } \\
\text { confirmed human infection with an influenza } \\
\text { virus and influenza disease as the clinical } \\
\text { consequence }\end{array}$ & $\begin{array}{l}\text { This should not be confused with influenza -like illness (ILI) } \\
\text { which has a European clinical case definition. A number } \\
\text { of other organisms and conditions can cause ILI. Equally, } \\
\text { influenza infection can be asymptomatic or cause symptoms } \\
\text { that do not meet the case definition or entirely different } \\
\text { symptoms. }\end{array}$ \\
\hline $\begin{array}{l}\text { Old and new seasonal } \\
\text { influenza }\end{array}$ & $\begin{array}{l}\text { Old: the seasonal influenza circulating } \\
\text { between } 1977 \text { (when human influenza } A\left(\mathrm{H}_{1} \mathrm{~N}_{1}\right) \\
\text { viruses re-emerged) and } 2008 \\
\text { New: influenza circulating from } 2010 \text { onwards }\end{array}$ & $\begin{array}{l}\text { It should not be assumed that the new (from } 2010 \text { onwards) } \\
\text { mix of seasonal viruses will have the same characteristics or } \\
\text { mortality as its predecessor. }\end{array}$ \\
\hline
\end{tabular}


TABLE 2

Methods of estimating influenza-related mortality

\begin{tabular}{|c|c|c|c|c|c|}
\hline Method & Description & Limitations and biases & Use in pandemic & $\begin{array}{l}\text { Use for seasonal } \\
\text { influenza }\end{array}$ & Reference \\
\hline Vital registration data & $\begin{array}{l}\text { Influenza mentioned on } \\
\text { death certificate. }\end{array}$ & $\begin{array}{l}\text { Especially weak in } \\
\text { older people and } \\
\text { people with chronic } \\
\text { medical conditions; will } \\
\text { underestimate total. }\end{array}$ & $\begin{array}{l}\text { Because of high profile } \\
\text { in pandemics may } \\
\text { become more sensitive } \\
\text { with increased testing } \\
\text { where facilities are } \\
\text { available. }\end{array}$ & $\begin{array}{l}\text { High specificity but can } \\
\text { be very insensitive; will } \\
\text { severely underestimate } \\
\text { total. }\end{array}$ & {$[13,21]$} \\
\hline $\begin{array}{l}2 . \\
\text { Laboratory-confirmed } \\
\text { deaths }\end{array}$ & $\begin{array}{c}\text { A death is only included } \\
\text { if there is laboratory } \\
\text { confirmation. }\end{array}$ & $\begin{array}{c}\text { High specificity but can } \\
\text { be very insensitive; will } \\
\text { always underestimate } \\
\text { totals, sometimes } \\
\text { severely. }\end{array}$ & $\begin{array}{l}\text { Because of high profile } \\
\text { in pandemics may } \\
\text { become more sensitive } \\
\text { with increased testing; } \\
\text { but during intense } \\
\text { transmission there are } \\
\text { only clinical diagnoses } \\
\text { and so this approach } \\
\text { will lose sensitivity. }\end{array}$ & $\begin{array}{c}\text { High specificity but can } \\
\text { be very insensitive; will } \\
\text { severely underestimate } \\
\text { total. }\end{array}$ & {$[21,31]$} \\
\hline $\begin{array}{l}3 . \\
\text { Statistical and } \\
\text { modelling techniques } \\
\text { (see Table } 4 \text { for more } \\
\text { detail) }\end{array}$ & $\begin{array}{l}\text { Estimates influenza- } \\
\text { attributed mortality } \\
\text { through comparing all- } \\
\text { cause or selected-cause } \\
\text { deaths during periods of } \\
\text { intense and no influenza } \\
\text { activitya; applies a } \\
\text { variety of models } \\
\text { which may or may not } \\
\text { be strengthened by } \\
\text { surveillance data. }\end{array}$ & $\begin{array}{l}\text { Without care can be } \\
\text { confounded by rises } \\
\text { in mortality due to } \\
\text { other causes; the best } \\
\text { approaches are further } \\
\text { informed by virological } \\
\text { surveillance and using } \\
\text { data on competing } \\
\text { causes (severe weather } \\
\text { and other infections). }\end{array}$ & $\begin{array}{l}\text { Requires age-specific } \\
\text { analyses and often } \\
\text { cannot be applied until } \\
\text { a year or more after } \\
\text { the event; most often } \\
\text { used for predictions } \\
\text { or investigating } \\
\text { the likely effects of } \\
\text { interventions, but can } \\
\text { be used for estimations } \\
\text { (now-casting). }\end{array}$ & $\begin{array}{c}\text { Without care results can } \\
\text { be confounded by rises } \\
\text { in mortality due to other } \\
\text { factor such as weather. } \\
\text { Method rarely used in } \\
\text { seasonal influenza in } \\
\text { Europe. }\end{array}$ & {$[21,32-35]$} \\
\hline $\begin{array}{l}4 . \\
\text { Weighting deaths by } \\
\text { years of potential life } \\
\text { lost (YPLL) }\end{array}$ & $\begin{array}{l}\text { Estimating and totalling } \\
\text { the numbers of years } \\
\text { of life that deaths } \\
\text { represent; can be } \\
\text { combined with other } \\
\text { methods such as 1-3. }\end{array}$ & $\begin{array}{l}\text { Useful in comparing } \\
\text { impact of deaths } \\
\text { affecting different age- } \\
\text { groups; limitations are } \\
\text { difficulties in knowing } \\
\text { the life expectancies for } \\
\text { people with underlying } \\
\text { illness; does not allow } \\
\text { for disability and work } \\
\text { productivity; can be } \\
\text { especially difficult to } \\
\text { apply to estimated } \\
\text { numbers of deaths and } \\
\text { deaths from multiple } \\
\text { causes (influenza } \\
\text { and an underlying } \\
\text { condition). }\end{array}$ & $\begin{array}{l}\text { Became more useful and } \\
\text { possible in the } 2009 \\
\text { pandemic in Europe } \\
\text { because of more deaths } \\
\text { being diagnosed and } \\
\text { laboratory-confirmed } \\
\text { than in seasonal } \\
\text { influenza. }\end{array}$ & $\begin{array}{l}\text { Can be very problematic } \\
\text { if the base is confirmed } \\
\text { deaths and only a few of } \\
\text { these are diagnosed. }\end{array}$ & $\begin{array}{c}\text { Using } \\
\text { individual } \\
\text { deaths: } \\
\text { [36]; using } \\
\text { statistical } \\
\text { approach: } \\
\text { [4] }\end{array}$ \\
\hline $\begin{array}{l}5 . \\
\text { Emerging infection } \\
\text { programme (US) }\end{array}$ & $\begin{array}{c}\text { Community-based } \\
\text { surveys, notably the } \\
\text { US emerging infection } \\
\text { programme. }\end{array}$ & $\begin{array}{l}\text { Especially helpful where } \\
\text { surveys are enduring } \\
\text { over years. May still } \\
\text { miss some cardiac and } \\
\text { cerebrovascular deaths } \\
\text { due to influenza. }\end{array}$ & $\begin{array}{c}\text { More accurate than 1-3; } \\
\text { in the } 2009 \text { pandemic } \\
\text { with its young age } \\
\text { profile, missing cardiac } \\
\text { and cerebrovascular } \\
\text { deaths may be less } \\
\text { important. }\end{array}$ & $\begin{array}{l}\text { More accurate method } \\
\text { than } 1-3 \text {, but will miss } \\
\text { cardiac and circulatory } \\
\text { deaths; this has not } \\
\text { been applied in Europe } \\
\text { because considerable } \\
\text { financial investment } \\
\text { would be needed. }\end{array}$ & [29] \\
\hline $\begin{array}{l}6 . \\
\text { Enhanced mortality } \\
\text { analysis (US) }\end{array}$ & $\begin{array}{l}\text { Laboratory-confirmed } \\
\text { deaths due to } \\
\text { pneumonia and } \\
\text { influenza from } 122 \text { US } \\
\text { cities. }\end{array}$ & $\begin{array}{c}\text { Also used to } \\
\text { calculate YPLL and } \\
\text { captures cardiac and } \\
\text { cerebrovascular deaths. }\end{array}$ & $\begin{array}{l}\text { More accurate than } 1-3 \\
\text { but may be subject to } \\
\text { biases from changes of } \\
\text { relationships during and } \\
\text { outside of pandemics. }\end{array}$ & More accurate than $1-3$ & [4] \\
\hline
\end{tabular}

US: United States.

a In the United States all age rapid mortality monitoring systems usually only includes diagnoses for influenza and pneumonia or all respiratory and circulatory diagnoses 
TABLE 3

European assessments of the mortality burden due to seasonal influenza until 2009

\begin{tabular}{|c|c|c|c|c|c|c|c|c|c|}
\hline 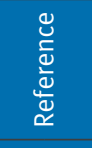 & $\overline{\tilde{\rho}}$ & $\overline{\mathrm{g}}$ & 氖 & 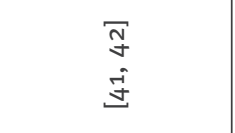 & $\overline{\widetilde{\vartheta}}$ & 寻 & 胥 & 茎 & $\stackrel{\varpi n}{\oplus}$ \\
\hline 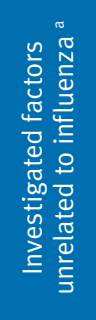 & 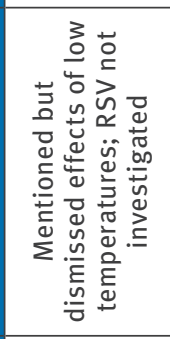 & 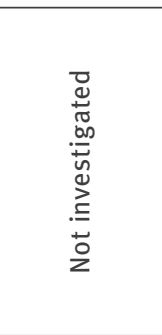 & 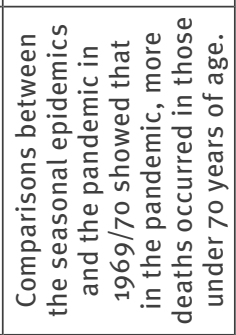 & 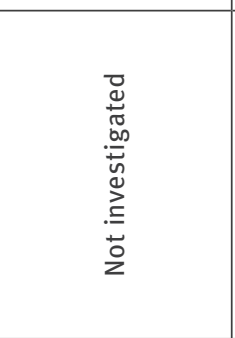 & 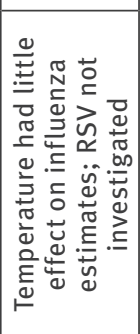 & 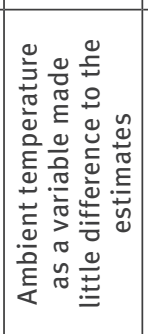 & & 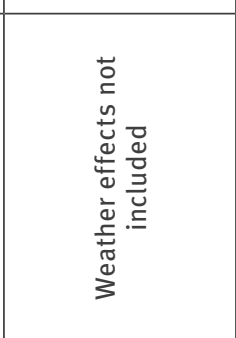 & 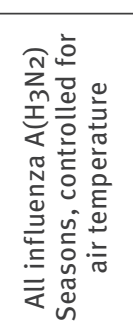 \\
\hline \multirow{4}{*}{ 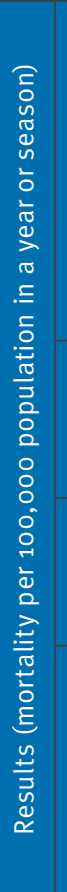 } & 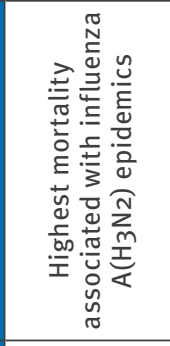 & 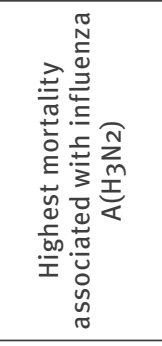 & 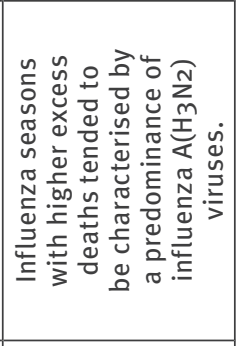 & 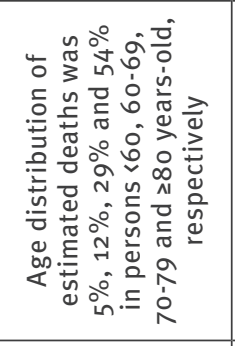 & 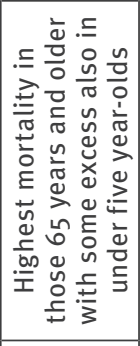 & 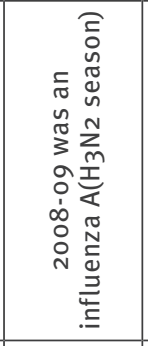 & & & 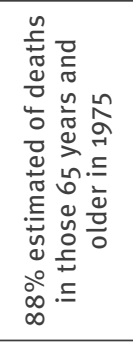 \\
\hline & 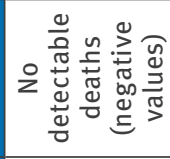 & $\frac{\stackrel{n}{o}}{\stackrel{n}{\omega}}$ & & 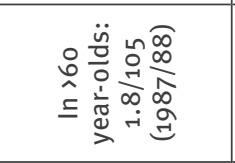 & 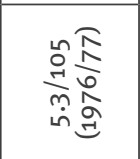 & \multirow{3}{*}{ 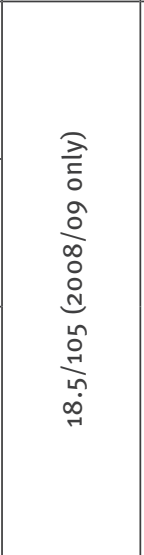 } & \multirow{3}{*}{ 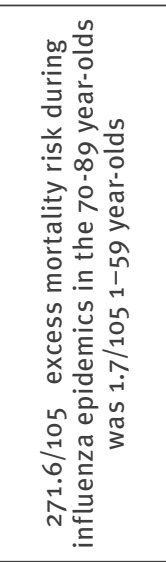 } & 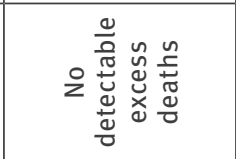 & 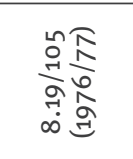 \\
\hline & 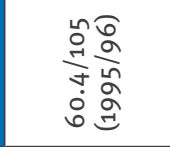 & 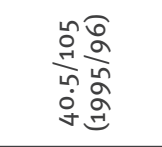 & & 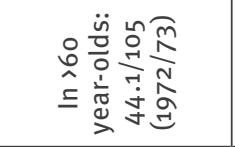 & 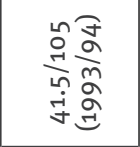 & & & 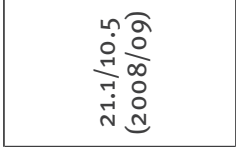 & 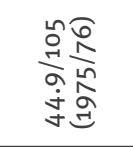 \\
\hline & 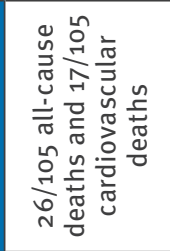 & 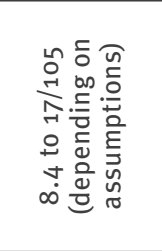 & 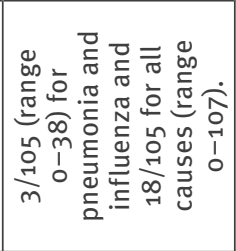 & 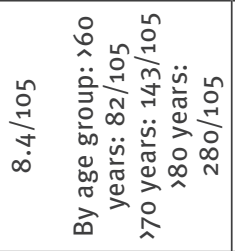 & $\begin{array}{l}\stackrel{n}{\stackrel{n}{N}} \\
\stackrel{N}{N} \\
\end{array}$ & & & $\begin{array}{l}\stackrel{n}{0} \\
\stackrel{1}{\infty} \\
\infty \\
\infty\end{array}$ & $\begin{array}{l}\stackrel{n}{0} \\
\stackrel{0}{0} \\
\dot{\sigma} \\
\text { a }\end{array}$ \\
\hline 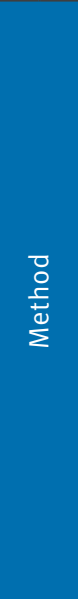 & 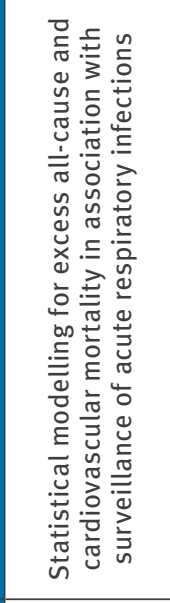 & 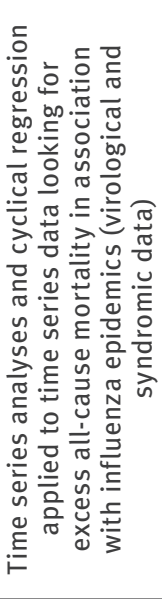 & 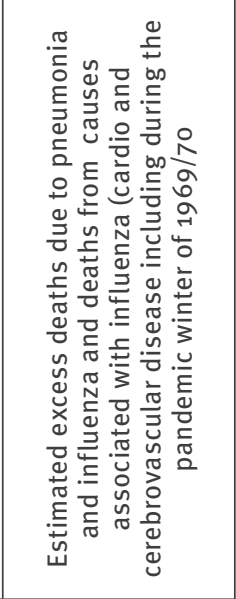 & 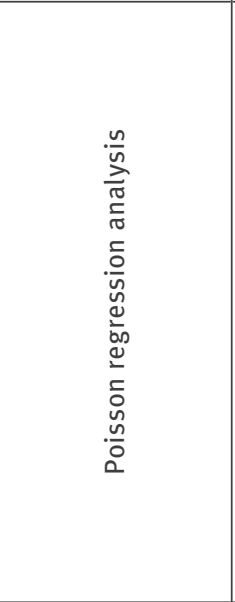 & 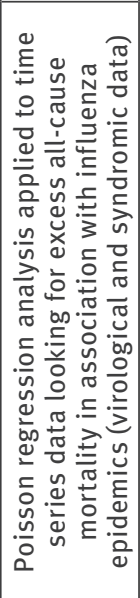 & 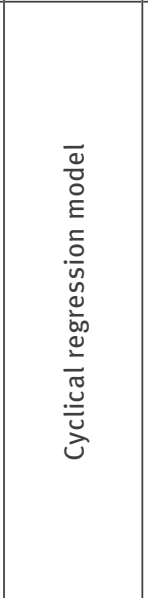 & 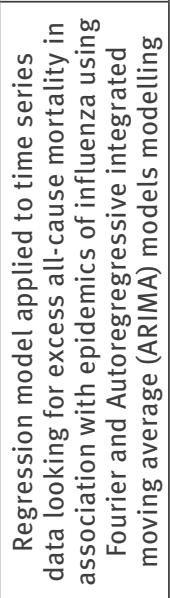 & 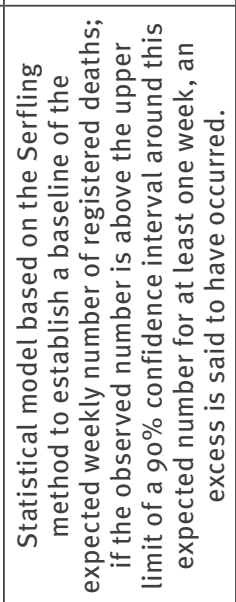 & 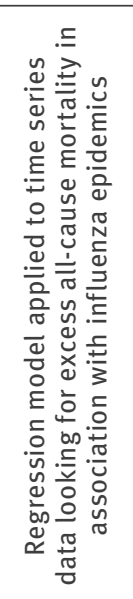 \\
\hline 항 & 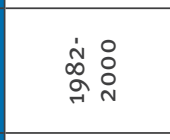 & 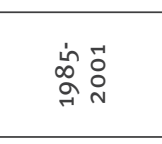 & 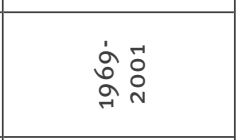 & 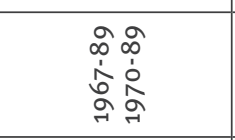 & $\begin{array}{l}\text { ñ } \\
\text { ño } \\
\text { à }\end{array}$ & $\begin{array}{l}\text { o } \\
\dot{0} \\
0 \\
0 \\
\text { N }\end{array}$ & 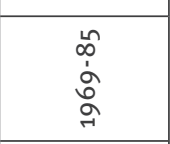 & 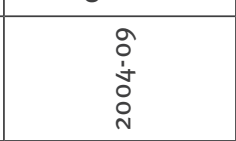 & 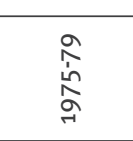 \\
\hline 意 & 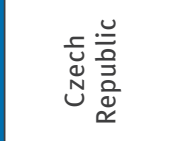 & 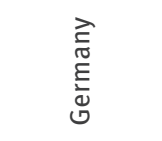 & $\frac{\geq}{\underline{\Xi}}$ & 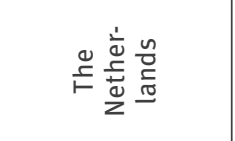 & 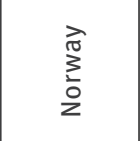 & 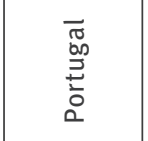 & 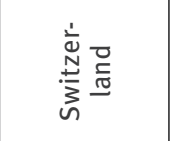 & 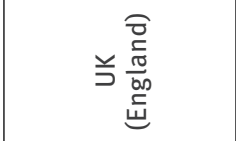 & 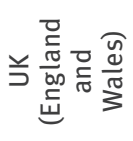 \\
\hline
\end{tabular}

UK: United Kingdom.

a ambient temperature and other respiratory viruses such as respiratory syncytial virus (RSV)

Source of Population Denominators: Eurostat total population data accessed June 2009 [48] and for England and

Wales Office for National Statistics [49]. 
Factors influencing observed influenza-related mortality

Factors leading to real differences in influenza-associated mortality

- Characteristics of the virus: virulence and transmissibility;

- Characteristics of the populations affected: demographics, access to healthcare, health seeking behaviour, social and economic circumstances, prevalence of risk factors;

- Levels of pre-existing immunity in the population (due to e.g. innate immunity, previous exposure to influenza viruses, vaccination, genetic susceptibility);

- Prevalence of complicating co-infections and underlying medical conditions in the affected populations.

Factors related to diagnosis and reporting of individual cases

- Different case definitions and methods of ascertainment;

- Different mortality reporting systems;

- Different routine and enhanced surveillance systems established in pandemics;

- Changing awareness of clinicians and their testing practices;

- Availability and quality of testing, testing policies;

- Different disease presentations.

the 2010/11 influenza season, there were over 600 deaths for which influenza was laboratory-confirmed and appeared on the death certificate [46]. However, interpretation of death certification data has to take into account the various ways how influenza infection results in premature death, how influenza infections are diagnosed and hence how it may be suspected or missed by clinicians (Box 1).

Some influenza deaths are due to primary viral infections, and in the 2009 pandemic, deaths were often associated with acute respiratory distress syndrome (ARDS), an exceedingly rare presentation of seasonal influenza [7,53-55]. But seasonal influenza can often result in secondary bacterial infections, which are dangerous in the very young, in people older than 65 years and those with chronic underlying conditions [56-58]. Influenza also precipitates death from cardiac and cerebrovascular complications, usually in those with preexisting underlying medical conditions [59]. Similar under-ascertainment can occur for laboratory diagnoses: Influenza infection is confirmed by the detection of the virus or its antigens. However, the period of viral shedding is usually short and frequently missed, especially by the time complications make the patient seek care. Hence a preceding influenza infection causing the complication is often unsuspected, or test-negative if a swab is taken [58].

During a pandemic, awareness of influenza is higher and diagnostic tests are more likely to be conducted, if they are available. But as the predictive value of clinical syndromes rises, clinicians are discouraged, or choose not to, take diagnostic specimens. Hence influenza cases may not be confirmed even when complications ensue [60].The magnitude of missed influenza cases and hence misdiagnosed deaths is hard to determine and will vary from country to country and over time $[13,52]$. This is also true for seasonal influenza. In the Netherlands for example, it was estimated that for every death registered in the period 1967-89 as due to seasonal influenza there were another 2.6 unrecognised influenza deaths [41]. While in a study in Denmark during the 2009 pandemic that compared laboratory-confirmed deaths with those estimated from a regression model suggested a ratio of 10 deaths for every one confirmed death [61]. It is likely that there was less under-identification in death certification and laboratory diagnosis during the 2009 pandemic than for seasonal influenza in industrialised countries because awareness of influenza among clinicians was high, testing more readily available and more countries used or developed enhanced surveillance systems 13,60]. There are some indications that since the 2009 pandemic, influenza diagnostic tests have been more widely available and used in hospitals. This, in combination with pandemic patients typically being younger than those dying from seasonal influenza, will probably result in influenza appearing more frequently on death certificates $[46,62]$.

A policy of reporting laboratory-confirmed deaths was adopted early on in the 2009 pandemic in European countries [8]. This resulted in high specificity and quality, but low sensitivity, of data on risk factors. This approach tends to miss influenza deaths especially in older people and those in whom influenza is the trigger for a severe illness of a non-specific nature (cerebrovascular and cardiovascular deaths) [59]. This age effect may have been less important in the 2009 pandemic because older age groups had some preexisting immunity and were less likely to be infected with the pandemic virus [63]. Also, since the criteria for using laboratory tests changed as the 2009 pandemic progressed, estimates relying on laboratory confirmation represent minimum totals, in particular for periods of intense transmission when a smaller proportion of clinical cases were being tested [6o].

Some countries, for example the US and Australia, have special reporting systems developed for particular groups, notably children, to inform decisions on vaccination policies. Such routine systems are not found in Europe. Laboratory-confirmed influenza deaths in children have been notifiable in the US since the 2004/05 influenza season. This proved especially helpful in contrasting the impact of seasonal influenza epidemics with the 2009 pandemic [64]. Similarly, the Australian Paediatric Surveillance Unit resumed winter surveillance for any severe complication of influenza in children during the pandemic [65].

\section{Statistical and modelling approaches}

Statistical and modelling approaches (Table 4) analyse death data from vital registries, looking at multiple codes that are expected to capture influenza-related deaths, i.e. pneumonia and influenza or all conditions coded as respiratory or cardiovascular $[66,67]$. There are trends in clinicians' preference for diagnosis and 
death classification, with influenza diagnosis being more likely when epidemics are prominent while they would at other times be classified as due to pneumonia [13]. Authorities in the US look for surges in the combined number of deaths due to influenza or pneumonia as a percentage of all deaths, at the same time as laboratory reports of influenza rise. However there will still be misclassification when identifying absolute numbers of respiratory deaths since even in a pandemic not all pneumonias are due to influenza and obviously cardiac and vascular deaths will be missed. The latter was probably less important in the 2009 pandemic with the protective cross-immunity in older people among whom cardiac and vascular deaths are most important $[59,63,68]$. In Europe the preference has been to use trends in all-cause mortality. Often deaths are considered by age group. The trends are then examined using a range of statistical and modelling techniques to look for excess deaths in association with influenza epidemics and pandemics (Table 4) [9,32,33,37,69-74].

Various other modelling techniques have been used (Table 4), including the original Serfling method to develop a baseline and detect variations from that [37,71]. More sophisticated multivariate regression models have been employed to calculate the mortality during periods of influenza activity in a given population controlling for potential confounders (e.g. weather or other circulating respiratory viruses), and estimate the excess compared with the expected mortality in the same period based on historical data (Tables 2 and 4). These models have used different death end points ranging from all-cause, cardiac and respiratory to pneumonia and influenza. Each method has its advantages and disadvantages (see Table 2 and 4). Methods that include competing causes of deaths (confounders) are preferable as they avoid overestimation of the attributed mortality. Excess mortality is then calculated with confidence intervals for pneumonia and influenza or for respiratory and circulatory causes or for all causes [10]. Extrapolation from the US data to Europe was the basis for estimate from the European Centre for Disease Prevention and Control (ECDC) of influenza-attributable deaths in seasonal influenza (1977/78 to 2008/09) of up to 38,500 per year in the countries of the European Union and European Free Trade Association in recent years $[10,75]$.

All-cause mortality attributable to influenza has been estimated in at least eight European countries (Table 3), sometimes with age-specific results [41]. However there are no routinely published outputs like those in the weekly influenza surveillance report FluView in the US [31,76] and therefore it is not possible to state a European normal seasonal influenza range. Estimating all cause mortality is also insensitive, as large numbers of influenza deaths need to take place before excess mortality is detectable across all age groups [13]. Hence paradoxically in a mild influenza season the best national estimate may appear as no excess of deaths due to influenza, when at the same time there are influenza related deaths that appear in death certificates $[13,46]$. There is, however, the danger of overestimating deaths attributable to influenza when important confounders are not considered such as other respiratory infections (notably respiratory syncytial virus) and ambient temperature.

TABLE 4

Statistical and modelling methods of estimating influenza-related mortality

\begin{tabular}{|c|c|c|c|c|}
\hline Method & $\begin{array}{l}\text { Inclusion of } \\
\text { virological } \\
\text { surveillance data }\end{array}$ & Advantages & Disadvantages & References \\
\hline $\begin{array}{l}\text { Peri- and summer } \\
\text { season rate difference } \\
\text { models }\end{array}$ & No & $\begin{array}{l}\text { Simple; can be undertaken with less } \\
\text { than five years worth of data;Does } \\
\text { not need virological data on type } \\
\text { and subtype; cannot be used where } \\
\text { seasonality of influenza is not clearly } \\
\text { known (aequatorial areas). }\end{array}$ & $\begin{array}{l}\text { Tend to produce inflated estimates } \\
\text { when compared to other methods; } \\
\text { Cannot be used to estimate } \\
\text { differences in viral type and subtype; } \\
\text { Other seasonal factors are hard to } \\
\text { control for. }\end{array}$ & {$[67,68]$} \\
\hline $\begin{array}{l}\text { Serfling least squares } \\
\text { cyclical regression } \\
\text { model }\end{array}$ & No & $\begin{array}{l}\text { Does not need virological data on } \\
\text { type and subtype; cannot be used } \\
\text { where seasonality of influenza is not } \\
\text { clearly known (aequatorial areas). }\end{array}$ & $\begin{array}{l}\text { Simple in comparison to other } \\
\text { regression approaches. } \\
\text { Cannot easily allow for other } \\
\text { variables such as other infections } \\
\text { (notably with respiratory syncytial } \\
\text { virus (RSV), severe winters etc. }\end{array}$ & {$[8,37,69]$} \\
\hline $\begin{array}{l}\text { Autoregregressive } \\
\text { integrated moving } \\
\text { average (ARIMA) } \\
\text { models }\end{array}$ & No & $\begin{array}{l}\text { Easy to update as more information is } \\
\text { collected. }\end{array}$ & $\begin{array}{l}\text { Complicated and can be difficult to } \\
\text { use; Provide few advantages over the } \\
\text { more simple linear models. }\end{array}$ & {$[32,65,72]$} \\
\hline
\end{tabular}


Methods of measuring mortality during a pandemic

Classical statistical approaches using historical influenza data may not readily be applied for pandemics because pandemic influenza activity often occurs outside of the traditional influenza seasons and baselines are hard to determine. More reliable data may only become available some time after the event and are subject to reanalysis even many years later $[4,16,19]$. Capturing mortality is particularly difficult in a pandemic, such as during the 2009 pandemic, which caused a relatively small number of deaths. A more sensitive approach is to look for age group-specific effects in younger people in whom background deaths are less frequent than in the elderly so that modest influenza-related signals may be detectable [77]. Another approach is age-specific regression modelling. Previously this has only been undertaken in individual European countries. Combining data from different EU countries and looking at age-specific excess mortality is more sensitive. This is the current approach used in the pilot European Mortality Monitoring Project (EuroMOMO). EuroMOMO found that overall all-cause mortality in the 2009 pandemic was within the expected range for seasonal influenza, but there was a short-term but significant increase in child mortality in the age-group of 5-14 year-olds [77]. A similar excess of deaths in children has been observed through regression modelling and enhanced surveillance and in the UK $[78,79]$. The latter indicated that many of the deaths were in children with underlying conditions. In addition, a disproportionate number of excess deaths was observed in certain ethnic minority groups [77]. The EuroMOMO and the UK approaches have an advantage over the US system in that they provide a measure of population impact almost in real time, and that sustained changes in mortality can be expressed as a proportion of the expected number of deaths. Individual case surveillance provides essential information on the epidemiological characteristics of the fatal cases which allows for the determination of risk factors and estimates of years of potential life lost (YPLL) [8o]).

Another approach developed for pandemic planning is to use predictive modelling, producing projections or forecasts as ranges of deaths. This is useful for planning purposes, but is especially vulnerable to uncertainty since these projections are usually based on assumptions of the epidemiologic characteristics of the virus gathered early in the pandemic or based on the characteristics of past pandemic viruses. These estimates are usually based on reasonable worst case scenario assumptions (i.e. on a severe pandemic, but one that countries can with preparation still cope with), and as such tend to produce a range of estimates for cases and deaths that are high in their upper bounds [81]. This can easily confuse the general public as it may be seen as a prediction for a pandemic. Hence, mortality estimates generated using a worst case scenario must be presented very carefully to policy makers and the media who can seize on and misinterpret upper estimates [82]. Accuracy in case and death estimates greatly increases as more robust surveillance data become available and are incorporated into the models [34]. Such revised estimates of possible numbers of deaths, based on updated epidemiological and virological data, have been called 'now-casting' [34,83,84].

Potentially the most accurate method for estimating pandemic influenza-related mortality is using preexisting population-based surveillance to estimate the absolute number of influenza-related deaths or to detect excess premature mortality associated with epidemics or pandemics. This has been done through the Emerging Infections Program of the US Centers for Disease Control and Prevention (CDC) which collects exhaustive hospital-based surveillance data in specific geographical areas $[29,85]$. This allowed the US CDC to estimate the number of influenza deaths by age group, deriving an all-age estimated range for the US in the first 12 months of the 2009 pandemic of between 8,870 and 18,300 deaths with a central estimate of 12,470 , which is equivalent to a population rate of $4 \cdot 14 / 10^{5}$. These numbers compare with 2,125 reported confirmed deaths (population rate $0.69 / 10^{5}$ ) [85]. From this it was possible to determine multipliers for the US that could be applied in that country to its all age or paediatric reported deaths to estimate true excess deaths $[29,85]$. However the US multipliers must not be applied in other countries.

A related US approach for estimating deaths caused by the pandemic applies the relationship seen between seasonal influenza and deaths coded as due to pneumonia and influenza and applying the observed agegroup distribution seen in virologically confirmed deaths. This has been extended to calculate estimates of deaths and YPLL using pneumonia and influenza excess deaths as the lower bound and all-cause excess deaths as the upper [4]. The YPLL approach incorporates important qualitative aspects of deaths in young people in the 2009 pandemic and allows for more accurate comparisons with seasonal influenza. To date in Europe, only the Netherlands has published YPLL figures for confirmed 2009 pandemic deaths, estimating that the minimum YPLL were similar to those from seasonal influenza [36]. There are, however, difficulties with the YPLL approach since individuals with chronic conditions who die from influenza often have a shorter expected life span and attributing their years of life lost entirely to influenza will result in an overestimation $[11,80]$. It is also possible that for the very elderly and very ill, influenza infection only brings forward death by a few weeks or months.

\section{Deaths due to the 2009 pandemic recorded on national websites versus deaths reported to ECDC}

Aside from the EuroMOMO project, there was no routine European system for monitoring mortality during the 2009 pandemic using statistical or modelling 
techniques [86]. Surveillance of individual severe influenza illness and influenza-related deaths was instituted for Europe and globally after the 2009 pandemic virus was first detected in North America [8]. Reports from EU Member States were published in the ECDC Weekly Influenza Surveillance Overview and reports from the World Health Organization (WHO) $[8,87,88]$. In addition active epidemic intelligence was undertaken by ECDC, monitoring official websites of ministries of health or other national authorities to collect information on fatal cases $[8,88]$. Data collected from websites were validated via the Early Warning and Response System (EWRS) where EU/EEA Member States reported additional information on fatal cases. The first fatal cases in Europe were reported in June 2009 during the spring/summer wave of the pandemic in the UK [8]. Through the 2009 summer, 10 to 25 deaths were announced weekly in the EU/EAA, with an increase in numbers around week 43 (week beginning 19 October) and continued to increase until week 50 (week beginning 7 December) when the total peaked at over 300 deaths/week. The Figure illustrates how the differences between the announced versus reported pandemic deaths were principally due to some countries reporting to ECDC and WHO only a small number of the cases they had announced on websites (names of countries have been removed).

The ECDC ceased active monitoring of websites in April 2010. By then the 30 EU/EFTA Member States had announced a total of 2,900 fatal cases, a population rate of $0.56 / 10^{5}$ with national rates varying eight- to nine-fold from 0.18 to $1.51 / 10^{5}$ [89]. National totals cited will have changed somewhat since April 2010 due to late reporting and data improvement. The official number of deaths reported to ECDC and WHO was lower. This was due to a few large countries hardly reporting any deaths (Figure). With the exception of age, comparing population rates of reported deaths yielded no obvious patterns [88]. It is likely that much of the differences in patterns are reflected by differences in diagnosis and reporting between countries. The age pattern of the cases reported was strikingly different from that observed with the previously circulating seasonal influenza (Table 5) $[61,67]$. Pandemic deaths were more often in children and young adults. Approximately $20 \%$ of deaths were in people over 65 years of age compared with the usual figure of around $90 \%$ for seasonal influenza deaths $[33,90,91]$. This likely reflects the underlying pre-existing immunity in the older sections of the population due to exposure to earlier similar influenza $A\left(\mathrm{H}_{1} \mathrm{~N}_{1}\right)$ viruses, which reduced their risk of infection and death $[63,68]$. However, elderly persons who were infected, had a significantly higher risk of dying than younger persons $[88,92]$. A number of national and international studies using individual data added important details, notably concerning the risk factors for deaths $[79,91,93,94]$. While these have confirmed that chronic underlying disease was a risk factor in adults and children, they found that between $18 \%$ and $30 \%$ of the deaths were in people without any

\section{FIGURE}

Cumulative confirmed fatalities due to influenza A(H1N1)pdm09, announced $(n=2,900)$ versus reported $(n=1,890)$, by country $^{\mathrm{a}}$, 15 April 2009-10 May 2010

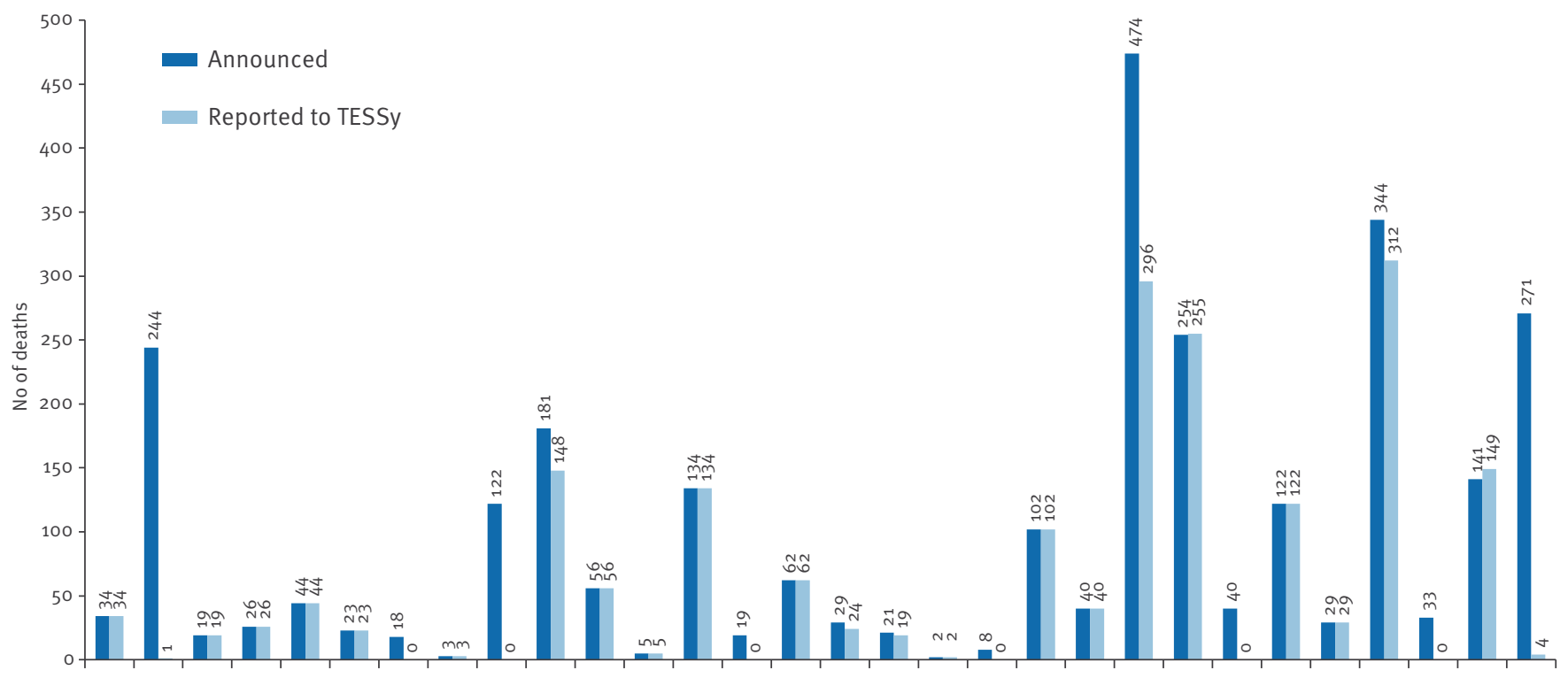

Each space on the $x$-axis represents an EU/EFTA Member State. The order has been randomised so as not to follow alphabetical order. 
chronic health condition $[24,79,90,93,94]$. A UK study examined ethnic group effects and found that children of southern Asian origin were at higher risk of death than white children, a finding replicated for hospitalisations but not for perinatal mortality $[79,95,96]$.

\section{Interpretation of European 2009 pandemic mortality data}

The 2,900 laboratory-confirmed deaths attributed to the $2009 A\left(\mathrm{H}_{1} \mathrm{~N}_{1}\right)$ pandemic reported by EU Member States are a minimum number and a considerable underestimate of the true mortality $[87,88]$. Given the very different crude population death rates announced by different countries it is likely that the multipliers to estimate a more accurate figure of premature deaths differ from country to country and no single multiplier should be applied [89]. Differences in rates probably reflect national variation in diagnosis, testing, test availability, awareness in clinicians, and access to care. It would be interesting to investigate the reasons for different death rates within the EU, since the pandemic virus did not change. The modelling approach in Denmark has cautiously derived an estimate of 312 influenza deaths, whereas only 30 laboratoryconfirmed deaths were observed. Hence Denmark has a multiplier of 10 and an estimated true death rate of up to 5.7 per 100,000 population [61]. While it is likely that many deaths were unreported, the magnitude of the underestimate almost certainly differs by country. There are likely to be unidentified pandemic deaths in older adults but they cannot be many or there would have been excesses in observed all-cause or older age mortality.

\section{TABLE 5}

Differences in the patterns of mortality during influenza seasons 2000/01 to 2008/09 and the 2009 influenza pandemic

\begin{tabular}{|c|c|c|}
\hline & Seasonal influenza $2000 / 01$ to $2008 / 09$ & 2009 pandemic influenza \\
\hline $\begin{array}{l}\text { Intensity of diagnostic } \\
\text { testing }\end{array}$ & $\begin{array}{l}\text { Compared to the pandemic there was } \\
\text { less testing for influenza }\end{array}$ & $\begin{array}{l}\text { More intensive testing than during seasonal epidemics, although to } \\
\text { varying extent between countries and over the period of the pandemic }\end{array}$ \\
\hline When deaths occurred & $\begin{array}{l}\text { In season - mostly starting after } \\
\text { Christmas in recent years, may have } \\
\text { coincided with extreme weather }\end{array}$ & $\begin{array}{l}\text { Started out of season with a spring/summer wave, then } \\
\text { an early autumn/winter wave in Europe }\end{array}$ \\
\hline $\begin{array}{l}\text { Experiencing severe } \\
\text { disease }\end{array}$ & $\begin{array}{l}\text { Those in clinical risk groups } \\
\text { and older people }\end{array}$ & $\begin{array}{c}\text { Young children, pregnant women and those in clinical risk groups. } \\
\text { About 30\% with severe disease were outside risk groups. } \\
\text { Many born before the mid-1950s were immune, } \\
\text { but those not experienced severe disease. }\end{array}$ \\
\hline Premature deaths & $\begin{array}{l}\text { Around } 90 \% \text { are considered to occur in } \\
\text { people } 65 \text { years or older }\end{array}$ & $\begin{array}{c}\text { In laboratory-confirmed reported deaths around } \\
80 \% \text { were under } 65 \text { years-old } \\
\text { Increase in all-cause deaths in children detected across eight EU } \\
\text { countries by EuroMOMO system }\end{array}$ \\
\hline $\begin{array}{l}\text { Mortality and years of } \\
\text { potential life lost (YPLL) }\end{array}$ & $\begin{array}{l}\text { Few confirmed deaths reported each } \\
\text { year in official statistics } \\
\text { Estimated using statistical methods to be } \\
\text { up to } 38,500 \text { on average in the EU }\end{array}$ & $\begin{array}{l}\text { Substantial numbers of confirmed deaths announced by EU/EFTA } \\
\text { Member States }(n=2,900) \text { but recognised to be an underestimate } \\
\text { Not estimated in any EU Member State but estimated in the US }\end{array}$ \\
\hline $\begin{array}{l}\text { Acute respiratory } \\
\text { distress syndrome }\end{array}$ & Extremely rare & $\begin{array}{l}\text { Uncommon but has been recorded in many } \\
\text { countries, even in young fit adults } \\
\text { Partially explained by the tropism of the pandemic virus for epithelial } \\
\text { receptors that predominate in the lung alveoli while the previous } \\
\text { seasonal viruses bind best to receptors found predominately in the } \\
\text { upper airways }\end{array}$ \\
\hline Pathological findings & $\begin{array}{l}\text { Viral pneumonia rare, but } \\
\text { secondary bacterial infections } \\
\text { more common in fatal cases }\end{array}$ & $\begin{array}{l}\text { Fatal viral pneumonias relatively common with alveolar lining cells, } \\
\text { including type I and type II pneumocytes the primary infected cells } \\
\text { More than } 25 \% \text { of fatalities also had bacterial infections }\end{array}$ \\
\hline
\end{tabular}


There is more certainty in the characteristics of the fatalities. In contrast to seasonal influenza, global deaths from the 2009 pandemic occurred more often among children and young adults, and a substantial proportion of fatal cases did not have underlying chronic health conditions (Table 5). As in the 1918 and 1957 pandemics, the 2009 influenza $A\left(\mathrm{H}_{1} \mathrm{~N}_{1}\right)$ pandemic affected mainly younger members of society with many but not all older people (born before 1960) possessing some levels of cross-protective immunity $[63,68,97,98]$. Qualitatively and quantitatively, the deaths in Europe also reflected this pattern (Table 5). Cautious application of the YPLL approach shown by the Dutch investigators is a better way to proceed [36].

It is instructive to note how misleadingly high the early estimates of case fatality rates in Mexico were, although they were at the time based on the best available data $[23,26]$. The early broad clinical experience in New York City (US), Melbourne (Australia) and the UK were more instructive for judging the mortality and severity of this pandemic than the initial impressions and numerical analyses from Mexico [99]. Due to the mild symptoms of many of the cases the true case fatality rates were impossible to measure. Infection fatality rates are more reliable because they are less affected by differing definitions of mild cases. If accurate case fatality rates are to be derived in a timely manner in future pandemics and provide population-based fatality rates for comparisons between countries prior preparation for early rapid seroepidemiological studies.will be needed [24,100-102].

\section{Recommendations for practice, surveillance and study}

Influenza epidemics and pandemics are important public health events with a significant impact at least on healthcare systems. What is needed are national routine systems for monitoring the annual numbers of influenza-associated deaths. Preferably methods should be consistent and corrected for confounding to avoid systematic overestimation. Monitoring international all-cause winter deaths during the influenza season through international surveillance building on the example of EuroMOMO is desirable. However, it is important to add data on cause. The EuroMOMO project has made an important start and includes more than ten EU countries. EuroMOMO now needs to grow and introduce analyses that can provide standard timely estimates of mortality attributable to influenza (both seasonal and pandemic), including cause-specific data. Regression modelling can provide a complementary approach to estimate the burden of influenza retrospectively and allows the opportunity to control for potential confounding factors. Participants of the annual meeting of the European Influenza Surveillance Network in 2011 (held jointly with WHO Regional Office for Europe) agreed there should be agreement on one or more preferred European methods for statistical national estimates of excess influenza deaths as well as preferred methods of formal individual death reporting in order to identify risk groups [102]. They further agreed that YPLL should be estimated as well as death totals, although such calculations need to allow for differing life expectancy in those with and without chronic conditions. In addition influenza infections should be suspected more readily as a potential diagnosis and more diagnostic tests should be used in hospitals. That will allow systematic investigation of the patterns of influenza-related premature deaths and their risk factors as these can indicate how these deaths and severe cases can best be prevented. This will require individual reporting of deaths particularly for key groups for whom vaccination and early treatment policy is uncertain, such as children, pregnant women and young healthy adults.

\section{References}

1. Monto AS, Comanor L, Shay DK, Thompson WW. Epidemiology of pandemic influenza: use of surveillance and modeling for pandemic preparedness. J Infectious Dis. 2006;194 Suppl 2:S92-7.

2. Kilbourne ED. Influenza pandemics of the 2oth century. Emerg Infectious Dis. 2006;12(1):9-14.

3. Henderson DA, Courtney B, Inglesby TV, Toner E, Nuzzo JB. Public health and medical responses to the 1957-58 influenza pandemic. Biosecur Bioterror. 2009;7(3):265-73.

4. Viboud C, Miller M, Olson D, Osterholm M, Simonsen L. Preliminary Estimates of Mortality and Years of Life Lost Associated with the $2009 \mathrm{~A} / \mathrm{H}_{1} \mathrm{~N}_{1}$ Pandemic in the US and Comparison with Past Influenza Seasons. PLoS Curr. 2010:RRN1153.

5. Viboud C, Boelle PY, Pakdaman K, Carrat F, Valleron AJ, Flahault A. Influenza epidemics in the United States, France, and Australia, 1972-1997. Emerg Infect Dis. 2004;10(1):32-9.

6. Simonsen L, Clarke MJ, Schonberger LB, Arden NH, Cox NJ, Fukuda K. Pandemic versus epidemic influenza mortality: a pattern of changing age distribution. J Infect Dis. 1998;178(1):53-60.

7. Shieh WJ, Blau DM, Denison AM, Deleon-Carnes M, Adem P, Bhatnager J, et al. 2009 Pandemic influenza $A\left(\mathrm{H}_{1} \mathrm{~N}_{1}\right)$ Pathology and pathogenesis of 100 fatal cases in the United States. Am J Pathol. 2010;177(1):166-75.

8. European Centre for Disease Prevention and Control (ECDC). The $2009 \mathrm{~A}\left(\mathrm{H}_{1} \mathrm{~N}_{1}\right)$ pandemic in Europe - A review of the experience. Stockholm: ECDC; 2010 . Available from: http:// www.ecdc.europa.eu/en/publications/Publications/101108 SPR_pandemic_experience.pdf

9. Simonsen L, Clarke MJ, Williamson GD, Stroup DF, Arden $\mathrm{NH}$, Schonberger LB. The impact of influenza epidemics on mortality: introducing a severity index. Am J Public Health. 1997;87(12):1944-50.

10. Centers for Disease Control and Prevention (CDC). Estimates of deaths associated with seasonal influenza --- United States, 1976-2007. MMWR Morb Mortal Wkly Rep. 2010;59(33):105762. MMWR Morb Mortal Wkly Rep.

11. Eickhoff TC, Sherman IL, Serfling RE. Observations on excess mortality associated with epidemic influenza. Md State Med J. 1962;11:104-110.

12. Sprenger MJ, Van Naelten MA, Mulder PG, Masurel N. Influenza mortality and excess deaths in the elderly, 1967-82. Epidemiol Infect. 1989;103(3):633-41.

13. Donaldson LJ, Rutter PD, Ellis BM, Greaves FE, Mytton OT, Pebody RG, et al. English mortality from A/H1N1. Comparisons with recent flu mortality. BMJ. 2010;340:c612.

14. Garske T, Legrand J, Donnelly CA, Ward H, Cauchemez S, Fraser $C$, et al. Assessing the severity of the novel influenza $A / \mathrm{H}_{1} \mathrm{~N}_{1}$ pandemic. BMJ. 2009;339:b2840.

15. Rizzo C, Bella A, Viboud C, Simonsen L, Miller MA, Rota MC, et al. Trends for influenza-related deaths during pandemic and epidemic seasons, Italy, 1969-2001. Emerg Infect Dis. 2007;13(5):694-9.

16. Johnson NP, Mueller J. Updating the accounts: global mortality of the 1918-1920 "Spanish" influenza pandemic. Bull Hist Med. 2002 Spring;76(1):105-15.

17. Dauer CC. Mortality in the $1957-58$ influenza epidemic. Public Health Rep. 1958;73(9):803-10. 
18. Alling DW, Blackwelder WC, Stuart-Harris CH. A study of excess mortality during influenza epidemics in the United States, 1968-1976. Am J Epidemiol. 1981;113(1):30-43.

19. Ansart S, Pelat C, Boelle PY, Carrat F, Flahault A, Valleron AJ. Mortality burden of the 1918-1919 influenza pandemic in Europe. Influenza Other Respi Viruses. 2009;3(3):99-106.

20. Murray CJ, Lopez AD, Chin B, Feehan D, Hill KH. Estimation of potential global pandemic influenza mortality on the basis of vital registry data from the 1918-20 pandemic: a quantitative analysis. Lancet. 2006;368(9554):2211-8.

21. Thompson WW, Moore MR, Weintraub E, Cheng PY, Jin X, Bridges CB, et al. Estimating influenza-associated deaths in the United States. Am J Public Health. 2009,99 Suppl 2:S225-30.

22. Pebody RG, McLean E, Zhao H, Cleary P, Bracebridge S, Foster $\mathrm{K}$, et al. Pandemic Influenza A ( $\left.\mathrm{H}_{1} \mathrm{~N}_{1}\right) 2009$ and mortality in the United Kingdom: risk factors for death, April 2009 to March 2010. Euro Surveill. 15(20):pii=19571. Available from: http:// www.eurosurveillance.org/ViewArticle.aspx?Articleld=19571

23. Transmission dynamics and impact of pandemic influenza $A$ (H1N1) 2009 virus. Wkly Epidemiol Rec. 2009;84(46):481-4.

24. Wu JT, Ma ES, Lee CK, Chu DK, Ho PL, Shen AL, et al. The infection attack rate and severity of 2009 pandemic $\mathrm{H}_{1} \mathrm{~N}_{1}$ influenza in Hong Kong. Clin Infect Dis. 2010;51(10):1184-91.

25. van den Wijngaard CC, van Asten L, Meijer A, van Pelt W, Nagelkerke NJ, Donker GA, et al. Detection of excess influenza severity: associating respiratory hospitalization and mortality data with reports of influenza-like illness by primary care physicians. Am J Public Health. 2010;100(11):2248-54.

26. Fraser C, Donnelly CA, Cauchemez S, Hanage WP, Van Kerkhove MD, Hollingsworth TD, et al. Pandemic potential of a strain of influenza $A\left(\mathrm{H}_{1} \mathrm{~N}_{1}\right)$ : early findings. Science. 2009;324(5934):1557-61.

27. World Health Organization (WHO). Recommended composition of influenza virus vaccines for use in the 2011-2012 northern hemisphere influenza season. Geneva: WHO; Feb 2011. Available from: http://www.who.int/entity/influenza/ vaccines/2011_02_recommendation.pdf

28. Farr W. Tenth annual report of Registrar-General xii 1847. London: H.M. Stationery Office; 1847.

29. Reed C, Angulo FJ, Swerdlow DL, Lipsitch M, Meltzer MI, Jernigan D, et al. Estimates of the prevalence of pandemic (H1N1) 2009, United States, April-July 2009. Emerg Infect Dis. 2009;15(12):2004-7.

30. Collins SD. Influenza-pneumonia mortality in a group of about 95 cities in the United States, 1920-29. Pub Health Rep. 1930;45:361-406.

31. Centers for Diseaase Prevention and Control (CDC). Overview of Influenza Surveillance in the United States. Atlanta: CDC; 2 Oct 2011. Available from: http://www.cdc.gov/flu/weekly/pdf/ overview.pdf

32. Choi K, Thacker SB. Mortality during influenza epidemics in the United States, 1967-1978. Am J Public Health. 1982;72(11):1280-3.

33. Thompson WW, Shay DK, Weintraub E, Brammer L, Cox $\mathrm{N}$, Anderson LJ, et al. Mortality associated with influenza and respiratory syncytial virus in the United States. JAMA. 2003;289(2):179-86.

34. Swine Flu UK. Planning Assumptions. London: Department of Health; 3 Sep 2009. Available from: http://www.dh.gov.uk/dr consum_dh/groups/dh_digitalassets/documents/digitalasset/ dh_104843.pdf

35. Tillett HE, Smith JW, Clifford RE. Excess morbidity and mortality associated with influenza in England and Wales. Lancet. 1980;1(8172):793-5.

36. Wielders CC, van Lier EA, van 't Klooster TM, van GageldonkLafeber AB, van den Wijngaard CC, Haagsma JA, et al. The burden of 2009 pandemic influenza $A\left(\mathrm{H}_{1} \mathrm{~N}_{1}\right)$ in the Netherlands. Eur J Public Health. 2012;22(1):150-7.

37. Serfling RE. Methods for current statistical analysis of excess pneumonia-influenza deaths. Public Health Rep. 1963;78(6):494-506.

38. Barker WH, Mullooly JP. Underestimation of the role of pneumonia and influenza in causing excess mortalityAm J Public Health. 1981;71(6):643-5.

39. Kyncl J, Prochazka B, Goddard NL, Havlickova M, Castkova J, Otavova M, et al. A study of excess mortality during influenza epidemics in the Czech Republic, 1982-2000. Eur J Epidemiol. 2005;20(4):365-71.

40. Zucs P, Buchholz U, Haas W, Uphoff H. Influenza associated excess mortality in Germany, 1985-2001. Emerg Themes Epidemiol. 2005;2:6

41. Sprenger MJ, Mulder PG, Beyer WE, Van Strik R, Masurel N. Impact of influenza on mortality in relation to age and underlying disease, 1967-1989. Int J Epidemiol. 1993;22(2):334-40.

42. Sprenger MJ, Mulder PG, Beyer WE, Masurel N. Influenza: relation of mortality to morbidity parameters--Netherlands, 1970-1989. Int J Epidemiol. 1991;20(4):1118-24

43. Gran JM, Iversen B, Hungnes O, Aalen 00. Estimating influenza-related excess mortality and reproduction numbers for seasonal influenza in Norway, 1975-2004. Epidemiol Infect. 2010;138(11):1559-68.

44. Nogueira PJ, Nunes B, Machado A, Rodrigues E, Gomez $V$, Sousa L, et al. Early estimates of the excess mortality associated with the 2008-9 influenza season in Portugal. Euro Surveill. 2009 May 7;14(18):pii=19194. Available from: http:// www.eurosurveillance.org/ViewArticle.aspx?Articleld=19194

45. Egger MJ, S. Spuhler, T. Zimmremann, H.P. Paccaud, F. Somaini, B. [Mortality in influenza epidemics in Switzerland 1969-1985]. Schweiz Med Wochenschr. 1989;119(13-14):434-9. [German].

46. Health Protection Agency (HPA). Surveillance of influenza and other respiratory viruses in the UK: 2010-2011. London: HPA; May 2011 . Available from: http://www.hpa.org.uk/ Publications/InfectiousDiseases/Influenza/1105influenzarepo rt/

47. Wong CM, Chan KP, Hedley AJ, Peiris JS. Influenza-associated mortality in Hong Kong. Clin Infect Dis. 2004;39(11):1611-7.

48. Eurostat. Statistics. Luxembourg: European Commission; [Accessed: November 2010] http://epp.eurostat.ec.europa.eu/ portal/page/portal/statistics/search_database

49. UK National Statistics. Population. Newport: Office for National Statistics; [Accessed: November 2010] . Population http://www.statistics.gov.uk/hub/population/index.html

50. Doshi P. Trends in recorded influenza mortality: United States, 1900-2004. Am J Public Health. 2008;98(5):939-45.

51. Noymer A. Influenza analysis should include pneumonia. Am Public Health. 2008;98(11):1927-8.

52. McLean E, Murdoch H, Reynolds A, Begum F, Thomas D, Smyth B, et al. Surveillance of influenza and other respiratory viruses in the United Kingdom: October 2008 to April 2009. Health Protection Report. 2009:3(39). Available from: http:// www.hpa.org.uk/hpr/archives/Infections/2009/respiratoryo9. htm\#suppo9

53. Patel M, Dennis A, Flutter C, Khan Z. Pandemic (H1N1) 2009 influenza. Br J Anaesth. 2010;104(2):128-42.

54. Writing Committee of the WHO Consultation on Clinical Aspects of Pandemic ( $\left.\mathrm{H}_{1} \mathrm{~N}_{1}\right) 2009$ Influenza, Bautista $\mathrm{E}$, Chotpitayasunondh T, Gao Z, Harper SA, Shaw M, et al. Clinical aspects of pandemic 2009 influenza $A\left(\mathrm{H}_{1} \mathrm{~N}_{1}\right)$ virus infection. $\mathrm{N}$ Engl J Med. 2010;362(18):1708-19.

55. World Health Organization (WHO). Comparing deaths from pandemic and seasonal influenza. Pandemic (H1N1) 2009 briefing note 20 . Geneva: WHO; 22 Dec 2009. Available from: http://www.who.int/csr/disease/swineflu/notes/ briefing_20091222/en/index.html

56. Thompson WW, Shay DK, Weintraub E, Brammer L, Bridges CB, Cox NJ, et al. Influenza-associated hospitalizations in the United States. JAMA. 2004;292(11):1333-40.

57. Centers for Disease Control and Prevention (CDC). Bacterial coinfections in lung tissue specimens from fatal cases of 2009 pandemic influenza A ( $\left.\mathrm{H}_{1} \mathrm{~N}_{1}\right)$ - United States, May-August 2009. MMWR Morb Mortal Wkly Rep. 2009;58(38):1071-4.

58. McGeer A, Green KA, Plevneshi A, Shigayeva A, Siddiqi N, Raboud J, et al. Antiviral therapy and outcomes of influenza requiring hospitalization in Ontario, Canada. Clin Infect Dis. 2007;45(12):1568-75.

59. Warren-Gash C, Smeeth L, Hayward AC. Influenza as a trigger for acute myocardial infarction or death from cardiovascular disease: a systematic review. Lancet Infect Dis. 2009;9(10):601-10.

6o. Lim MB, Bermingham A, Edmunds J, Fragaszy J, Harvey G, Johnson A, et al.Flu Watch. Community burden of Influenza during three influenza seasons and the summer wave of the $2009 \mathrm{H}_{1} \mathrm{~N}_{1}$ pandemic in England - implications for interpretation of surveillance data. Options for the Control of Influenza VII Options Conference; 3-7 Sep 2010; Hong Kong, China. P-321.

61. Mølbak K, Widgren K, Jensen KS, Ethelberg S, Andersen PH, Christiansen $\mathrm{AH}$, et al. Burden of illness of the 2009 pandemic of influenza $A\left(\mathrm{H}_{1} \mathrm{~N}_{1}\right)$ in Denmark. Vaccine. 2011;29 Suppl 2:B63-B9.

62. van Gageldonk-Lafeber AB, Riesmeijer RM, Friesema IHM, Meijer A, Isken LD, Timen A, et al. Case-based reported mortality associated with laboratory-confirmed influenza $A\left(\mathrm{H}_{1} \mathrm{~N}_{1}\right) 2009$ virus infection in the Netherlands: the 2009-2010 pandemic season versus the 2010-2011 influenza season. BMC Public Health. 2011;11:758. 
63. Hancock K, Veguilla V, Lu X, Zhong W, Butler EN, Sun H, et al. Cross-reactive antibody responses to the 2009 pandemic $\mathrm{H}_{1} \mathrm{~N}_{1}$ influenza virus. N Engl J Med. 2009;361(20):1945-52.

64. Cox CM, Blanton L, Dhara R, Brammer L, Finelli L. 2009 Pandemic Influenza A ( $\left.\mathrm{H}_{1} \mathrm{~N}_{1}\right)$ Deaths among Children-United States, 2009-2010. Clin Infect Dis. 2011;52 Suppl 1:S69-S74.

65. Australian Paediatric Surveillance Unit (APSU). APSU Update. Westmead: APSU; Aug 2010. Available from: http://www.apsu.org.au/download. cfm?DownloadFile=C7472E49-EA8F-7A9B-6ACA495A88D7DF11

66. Barker WH, Mullooly JP. Influenza vaccination of elderly persons. Reduction in pneumonia and influenza hospitalizations and deaths. JAMA. 1980;244(22):2547-9.

67. Choi K, Thacker SB. From the centers for disease control. Improved accuracy and specificity of forecasting deaths attributed to pneumonia and influenza. J Infect Dis. 1981;144(6):606-8.

68. Aho M, Lyytikainen O, Nyholm J, Kuitunen T, Ronkko E, Santanen R, et al. Outbreak of 2009 pandemic influenza $A\left(H_{1} N_{1}\right)$ in a Finnish garrison - a serological survey. Euro Surveill. 2010;15(45):pii=19709. Available from: http://www. eurosurveillance.org/ViewArticle.aspx?Articleld=19709

69. Barker WH, Mullooly JP. Impact of epidemic type A influenza in a defined adult population. Am J Epidemiol. 1980;112(6):798-811.

70. Barker WH, Mullooly JP. “A study of excess mortality during influenza epidemics in the United States, 1968-1976". Am J Epidemiol. 1982;115(3):479-480.

71. Lui KJ, Kendal AP. Impact of influenza epidemics on mortality in the United States from October 1972 to May 1985. Am J Public Health. 1987;77(6):712-6.

72. Thompson WW, Weintraub E, Dhankhar P, Cheng PY, Brammer L, Meltzer MI, et al. Estimates of US influenza-associated deaths made using four different methods. Influenza Other Respi Viruses. 2009;3(1):37-49.

73. Neuzil KM, Maynard C, Griffin MR, Heagerty P. Winter respiratory viruses and health care use: a populationbased study in the northwest United States. Clin Infect Dis. 2003;37(2):201-7.

74. Stroup DF, Thacker SB, Herndon JL. Application of multiple time series analysis to the estimation of pneumonia and influenza mortality by age 1962-1983. Stat Med. 1988;7(10):1045-59.

75. ECDC. Revised estimates of deaths associated with seasonal influenza in the US Stockholm: ECDC; 2010 [29/11/2010]; Available from: http://ecdc.europa.eu/en/activities/sciadvice/ Lists/ECDC\%20Reviews/ECDC DispForm.aspx? List $=512 \mathrm{ff} 74 \mathrm{f} \%$ 2D77d4\%2D4ad8\%2Db6d6\%2Dbfof23083f30\&ID=952\&RootFo Ider $=\%$ 2Fen $\%$ 2Factivities $\%$ 2Fsciadvice $\% 2$ FLists $\% 2$ FECDC $\% 20$ Reviews

76. Centers for Disease Control and Prevention (CDC). FluView. Weekly influenza surveillance report. Atlanta: CDC. Available from: http://www.cdc.gov/flu/weekly/

77. Mazick A, Gergonne B, Wuillaume F, Danis K, Vantarakis A, Uphoff $\mathrm{H}$, et al. Higher all-cause mortality in children during autumn 2009 compared with the three previous years: pooled results from eight European countries. Euro Surveill.15(5):pii=19480. Available from: http://www. eurosurveillance.org/ViewArticle.aspx?Articleld $=19480$

78. Hardelid P, Andrews N, Pebody R. Excess mortality monitoring in England and Wales during the influenza $A\left(\mathrm{H}_{1} \mathrm{~N}_{1}\right) 2009$ pandemic. Epidemiol Infect. 2011;139(9):1431-9.

79. Sachedina N, Donaldson LI. Paediatric mortality related to pandemic influenza $\mathrm{A} \mathrm{H} 1 \mathrm{~N}_{1}$ infection in England: an observational population-based study. Lancet. 2010;376(9755):1846-52.

80. Gardner JW, Sanborn JS. Years of potential life lost (YPLL)-what does it measure? Epidemiology. 1990;1(4):322-9.

81. Pandemic flu. A national framework for responding to an influenza pandemic. London: Department of Health; 2007. Available from: http://www.dh.gov.uk/prod_consum_dh/ groups/dh_digitalassets/@dh/@en/documents/digitalasset/ dh_080745.pdf

82. Abraham T. The price of poor pandemic communication. BMJ. 2010;340:C2952.

83. European Center for Disease Prevention and Control (ECDC). Revised pandemic 2009 planning assumptions for Europe. Stockholm: ECDC; 16 Sep 2009. Available from: http://www. google.se/url?sa $=t \& r c t=j \& q=\& e s r c=s \&$ source $=$ web \&cd $=2 \& v e$ $\mathrm{d}=0$ CDgQFjAB\&url=http $\% 3 \mathrm{~A} \% 2 \mathrm{~F} \% 2 \mathrm{Fecdc}$.europa.eu\%2Fen $\% 2$ Factivities\%2Fsciadvice\%2FLists\%2FECDC\%2520Reviews\%2FE CDC DispForm.aspx\%3FList\%3D $512 \mathrm{ff} 74 \mathrm{f}-77 \mathrm{~d} 4-4$ ad8-b6d6-bfo f23083f30\%26ID\%3D650\%26MasterPage \%3D1\%26PDF\%3Dtr ue\&ei=nCiNT72bHMqQ4gSX4ITbDw\&usg=AFQjCNFDbPJANxq6 XA_xQm5ruyDYbSpQRw.
84. European Center for Disease Prevention and Control (ECDC). Now-casting and short-term forecasting during influenza pandemics. A focused developmental ECDC workshop. Meeting Report. Stockholm: ECDC; 29-30 November 2007. Available from: http://www.ecdc.europa.eu/en/publications/ Publications/0711_MER_Forecasting_during_Influenza_ Pandemics.pdf

85. Centers for Disease Control and Prevention (CDC). Updated CDC Estimates of $2009 \mathrm{H}_{1} \mathrm{~N}_{1}$ Influenza Cases, Hospitalizations and Deaths in the United States, April 2009 - April 10, 2010. Atlanta: CDC; 14 May 2009. Available from: http://www.cdc. gov/h1n1flu/estimates_2009_h1n1.htm

86. Molbak K. Estimating the mortality and Years of Potental Life Lost attributable to influenza to direct public health action. 2010 European Scientific Conference on Applied Infectious Disease Epidemiology (ESCAIDE); 11-13 Nov 2010; Lisbon, Portugal.

87. World Health Organization Regional Office for Europe (WHO/ Europe). Guidance for influenza surveillance in humans. Copenhagen WHO/Europe; May 2011. Available from: http:// www.euro.who.int/document/e92738.pdf

88. Amato-Gauci A, Zucs P, Snacken R, Ciancio B, Lopez V, Broberg $E$, et al. Surveillance trends of the 2009 influenza $A\left(\mathrm{H}_{1} \mathrm{~N}_{1}\right)$ pandemic in Europe. Euro Surveill. 2011;16(26): pii=19903. Available from: http://www.eurosurveillance.org/ViewArticle. aspx?Articleld $=19903$

89. European Center for Disease Prevention and Control (ECDC). Number of fatal cases. Stockholm: ECDC; 3 May 2010. Available from: http://ecdc.europa.eu/en/healthtopics/H1N1/ epidemiological_data/Pages/number_confirmed_fatal_2009_ pandemic_influenza_cases.aspx

90. Health Protection Agency (HPA). Pandemic ( $\left.\mathrm{H}_{1} \mathrm{~N}_{1}\right) 2009$ in England: an overview of initial epidemiological findings and implications for the second wave. London: HPA; 2 Dec 2009. Available from: http://www.hpa.org.uk/web/HPAwebFile/ HPAweb_C/1258560552857Pandemic (H1N1) 2009 in England: an overview of initial epidemiological findings and implications for the second wave

91. van Gageldonk-Lafeber AB, Hooiveld M, Meijer A, Donker GA, Veldman-Ariesen $M-J$, van der Hoek W, et al. The relative clinical impact of 2009 pandemic influenza $A\left(\mathrm{H}_{1} \mathrm{~N}_{1}\right)$ in the community compared to seasonal influenza in the Netherlands was most marked among 5-14 year olds. Influenza Other Respi Viruses. 2011;5(6):e513-20.

92. Devaux I, Kreidl P, Penttinen P, Salminen M, Zucs P, Ammon A. Initial surveillance of 2009 influenza $A\left(\mathrm{H}_{1} \mathrm{~N}_{1}\right)$ pandemic in the European Union and European Economic Area, AprilSeptember 2009. Euro Surveill. 2010;15(49):pii=19740. Available from: http://www.eurosurveillance.org/ViewArticle. aspx?Articleld $=19740$

93. Van Kerkhove MD, Vandemaele KA, Shinde V, JaramilloGutierrez G, Koukounari A, Donnelly CA, et al. Risk Factors for Severe Outcomes following 2009 Influenza $A\left(\mathrm{H}_{1} \mathrm{~N}_{1}\right)$ Infection: A Global Pooled Analysis. PLoS Med. 2011;8(7):e1001053.

94. Pebody RG, McLean E, Zhao H, Cleary P, Bracebridge S, Foster K, et al. Pandemic Influenza A ( $\left.\mathrm{H}_{1} \mathrm{~N}_{1}\right) 2009$ and mortality in the United Kingdom: risk factors for death, April 2009 to March 2010. Euro Surveill. 2010;15(20):pii=19571. Available from: http://www.eurosurveillance.org/ViewArticle. aspx?Articleld $=19571$

95. Nguyen-Van-Tam J, Openshaw PJM, Hashim A, Gadd EM, Lim WS, Semple MG, et al. Risk factors for hospitalisation and poor outcome with pandemic $\mathrm{A} / \mathrm{H}_{1} \mathrm{~N}_{1}$ influenza: United Kingdom first wave (May-September 2009). Thorax. 2010;65(7):645-51.

96. Pierce M, Kurinczuk JJ, Spark P, Brocklehurst $P$, Knight $M$, UKOSS. Perinatal outcomes after maternal 2009/H1N1 infection: national cohort study. BMJ. 2011;342:d3214.

97. Broberg E, Nicoll A, Amato-Gauci A. Seroprevalence to $\mathrm{A}\left(\mathrm{H}_{1} \mathrm{~N}_{1}\right) 2009$ virus - where are we? Clin Vaccine Immunol. 2011;18(8):1205-12.

98. Seroepidemiological studies of pandemic influenza $A\left(\mathrm{H}_{1} \mathrm{~N}_{1}\right)$ 2009 virus. Wkly Epidemiol Rec. 2010;85(24):229-35.

99. European Center for Disease Prevention and Control (ECDC). Pandemic ( $\left.\mathrm{H}_{1} \mathrm{~N}_{1}\right) 2009$ influenza. ECDC Interim risk assessment. Stockholm: ECDC; 21 Aug 2009. Available from: http://ecdc.europa.eu/en/healthtopics/H1 1 1/ Documents/1001_RA_090821.pdf

100. Van Kerkhove MD, Asikainen T, Becker NG, Bjorge S, Desenclos JC, dos Santos T, et al. Studies needed to address public health challenges of the $2009 \mathrm{H}_{1} \mathrm{~N}_{1}$ influenza pandemic: insights from modeling. PLoS Med. 2010;7(6):e1000275.

101. Lipsitch M, Riley S, Cauchemez S,Ghani AC, Ferguson NM. Managing and reducing uncertainty in an emerging influenza pandemic. N Engl J Med. 2009;361(2):112-5.

102. Laurie KL, Huston P, Riley S, Katz JM, Willison DJ, Tam JSet al. Influenza serological studies to inform public 
health action: best practices to optimise timing, quality and reporting. Influenza Other Respi Viruses. Forthcoming. DOI: 10.1111/j.1750-2659.2012.0370b.x.

103. World Health Organization Regional Office for Europe (WHO/Europe), European Center for Disease Prevention and Control (ECDC). Meeting on influenza surveillance. Ljubljana, Slovenia, 7-9 June 2011. Summary report. Copenhagen: WHO/ Europe; 2011. Available from: http://www.euro.who.int/_data/ assets/pdf_file/0007/155509/e96072.pdf 